\title{
Re-Evaluation of Bovine Fiber Biomass as Exploitable Keratinous Bio-Resource for Biomedical and Industrial Applications
}

\author{
Isiaka Oluwole Oladele ${ }^{1,2^{*}}$, Jimmy Lolu Olajide ${ }^{1,3,4^{*}}$, Oluyemi Ojo Daramola1, Kofi Bismarck Siaw ${ }^{1}$ \\ ${ }^{1}$ Department of Metallurgical and Materials Engineering, Federal University of Technology, Akure, Nigeria \\ ${ }^{2}$ African Materials Science and Engineering Network (AMSEN) A Carnegie-IAS (RISE) Network (FUTA Node), Akure, Nigeria \\ ${ }^{3}$ Department of Mechanical Engineering, Elizade University, Ilara-Mokin, Nigeria \\ ${ }^{4}$ Division of Computational Materials Science and Prototype Engineering Development, Quantum Simutech Enterprise, Ilorin, \\ Nigeria \\ Email: *jimmylolu@gmail.com, *wolesuccess2000@yahoo.com, ojaythompsoms@yahoo.com, bismarck20@yahoo.com
}

How to cite this paper: Oladele, I.O., Olajide, J.L., Daramola, O.O. and Siaw, K.B. (2017) Re-Evaluation of Bovine Fiber Biomass as Exploitable Keratinous Bio-Resource for Biomedical and Industrial Applications. Journal of Minerals and Materials Characterization and Engineering, 5, $1-17$

http://dx.doi.org/10.4236/jmmce.2017.51001

Received: November 13, 2016

Accepted: December 13, 2016

Published: December 16, 2016

Copyright $\odot 2017$ by authors and Scientific Research Publishing Inc. This work is licensed under the Creative Commons Attribution International License (CC BY 4.0).

http://creativecommons.org/licenses/by/4.0/

\begin{abstract}
In claim of developing ecologically-friendly and low cost polymeric materials, some polymer scientists and engineers have focused on improving the properties of polymer composites with natural fibers. One typical example of these natural fibers currently used as reinforcements in low load-bearing polymer composites is bovine fiber which is traditionally a waste from slaughterhouse. However, nature has designed natural fibers with anisotropic properties which may not augur well for the development of polymer composites with guaranteed field-proven reliability. Nonetheless, unlike vegetal fibers, most animal fibers can be alternatively exploited for keratinous applications. In the present study, the tensile properties, crude protein contents and variations in elemental distribution of hair fibers obtained from three breeds of bovine found in Nigeria were investigated. The hair fibers were characterized by ultimate testing machine, proximate analysis and scanning electron microscopy with energy dispersive X-ray spectroscopy. Superlative Young's modulus and tensile strength among the fibers were found to be $0.98989 \mathrm{GPa}$ and 0.56158 $\mathrm{MPa}$, respectively. The determined crude protein contents of the fibers ranged between $35 \%$ and $40 \%$. Also, single hair fibers from each bovine breed showed significant variations in elemental distribution along their longitudinal sections which translates to anisotropic chemical and mechanical properties. However, the mean spectral values of the principal elements that constitute amino acids in the fibers are in the same range with that of human hair fibers with a successful record of keratinous applications.
\end{abstract}

\section{Keywords}

Biological Materials, Keratin Sources, Fiber Chemistry, Natural Fibers, Ecological Welfare 


\section{Introduction}

Critical reviews on the idea of radically replacing synthetic fibers (SFs) with Natural Fibers (NFs) in Polymer Composites (PCs) have revealed that this approach is defective and equally impracticable [1] [2]. Although, there are strong claims that NF reinforced PCs (NFRPCs) have the unprecedented advantages of improving ecological welfare by dwindling the effects of carbon footprints in our environment, their second-rate performance cannot be overlooked [3] [4] [5] [6].

This intellectual dispute subsequently resulted in a complicated confusion that prominent materials scientists have painstakingly tried to clarify since the invasion of NFs in PCs development [7] [8]. These scientists clearly pointed out that the development of a reliable engineering material goes beyond its cheapness and whether it is environmentally-friendly or not. It is basically dependent on its ability to withstand the test of time under the harshest service conditions for which it was designed; hence an optimum combination of properties is indispensable in materials development [9].

The foregoing clarification eventually culminated in a lot of researchers with keen interest in NFs trying assiduously to strike a balance between NFRPCs and SFRPCs. The consequent approaches to upgrade the properties of NFRPCs include fiber surface modification by chemical treatments, polymer matrix modification and the deployment of coupling agents [10] [11] [12] [13].

Nonetheless, these approaches still failed to be NFRPCs' saving grace despite reducing the economic viability of developing them. According to some researchers, the economic viability of developing NFRPCs is another major claim that led to the express switch from SFRPCs to NFRPCs [14].

During the advent of NFRPCs, the vegetal fibers (VFs) were the most exploited NFs. However, due to their associated drawbacks such as hydrophilic nature, dimensional instability at high temperatures and poor adhesive strength (wettability) [15] [16], some researchers substantially began to consider animal fibers (AFs) free of these deficiencies as suitable alternatives [17] [18] [19] [20] [21].

At first, the diversion into AFRPCs showed some great prospects; however, the problem of great anisotropy in their properties makes it difficult to develop AFRPCs with desired engineering properties [22] [23].

However, unlike VFs, most AFs are biological wastes such as avian feathers and mammalian hairs which are generated across the globe by agro-industrial industries in billions tons per year [24]. Most of these wastes with no interested end-users are usually getting rid of in very unsanitary manners such as burning, singeing and scrapheap deposition. These methods pose serious threats to our ecological welfare and therefore require exigent control measures [25].

On the bright side, most of these AFs are keratinous materials; that is, they are potential bio-resources for keratin extraction [26] [27].

Keratins and their derivatives are extensively used for biomedical, cosmetic, industrial and agricultural applications. Keratin films and keratin-based films 
are used in ocular surface reconstruction, drug delivery systems and treatment of acute myocardial infarction. Keratin hydrogels are used in peripheral nerve repair and as homeostatic agents. Keratin powders are used in wound healing and bone regeneration [28] [29]. Keratin hydrolysates are used as anti-ageing cream, hair rebuilding shampoo, hair conditioner, hair cream, organic fertilizers, filler for biodegradable polymers and tanning agent (replacement for chromium sulfate) in leather processing industries [30] [31] [32].

Hitherto, chicken feathers, animal wools and human hairs have been the major bio-resources exploited for keratin extraction with little attention on bovine hair, hooves and horns [33] [34] [35] [36] [37].

Of interest to the present study is whether Bovine Hair Fiber (BHF) should remain an emerging engineering material for AFRPCs development or should be considered a keratinous bio-resource.

The present study investigated the tensile properties, proximate compositions and variations in elemental distribution (along longitudinal sections) of BHFs obtained from three different breeds of bovines found in Nigeria.

\section{Materials and Methods}

\subsection{Materials}

The materials used in this research were basically White Bovine Hair Fiber (WHBHF), Black Bovine Hair Fiber (BLBHF) and Brown Bovine Hair Fiber (BRBHF) obtained from healthy White Fulani, Forest Muturu and Ankole-Watusi bovine breeds, respectively. The BHFs were obtained from the tail sections of each bovine breed. In order to have full knowledge of the BHFs, they were collected from a cattle ranch in the Federal University of Technology, Akure (FUTA), Ondo State, Nigeria. Ages of the bovines were 5 years \pm 6 months at the time of collection; the diameters of the collected BHFs ranged between 65 and 67 $\mu \mathrm{m}$ and their lengths ranged between 50 and $60 \mathrm{~mm}$. The bovines are allowed to graze under free-range system. The average temperature across the year in this part of Nigeria varies between $23.55^{\circ} \mathrm{C} \pm 0.423^{\circ} \mathrm{C}$ and $37.54^{\circ} \mathrm{C} \pm 0.23^{\circ} \mathrm{C}$ in the wet and dry seasons, respectively.

\subsection{Methods}

\subsubsection{Fiber Preparation}

The as-obtained BHFs from FUTA cattle ranch were thoroughly washed and rinsed with detergent and warm distilled water to render them free from impurities such as dust, oil and grease. Thereafter, the cleaned BHFs were dried for 21 days at $25^{\circ} \mathrm{C} \pm 2{ }^{\circ} \mathrm{C}$ to prepare them for tensile test, proximate analysis and Scanning Electron Microscopy with Energy Dispersive X-ray Spectroscopy (SEM-EDS).

\subsubsection{Tensile Test}

Till date, perfect methods of evaluating the actual tensile properties of a single NF are still non-existent. Most researchers invariably use the longitudinal tensile 
modulus (which is always higher than the transverse modulus) of NFs to predict the mechanical behavior of NFRPCs. However, some researchers who considered this approach defective resorted to using the Young's modulus from a bundle of NFs for predicting the performance of NFRPCs [38] [39]. Both approaches still have their associated drawbacks owing to the anisotropic properties of NFs [40]. Of interest to the present study is the modulus of a single fiber, hence, the first approach was adopted.

The tensile properties of the BHFs were evaluated in compliance with ASTM D3822-07 standard [41] with the aid of an INSTRON 5965 universal testing machine. Uniaxial tensile tests were conducted on single fibers with close aspect ratios form each bovine breed. $250 \mathrm{~N}$ capacity pneumatic side acting grips were used along with $25 \times 25 \mathrm{~mm}$ rubber coated jaw faces to hold the BHFs. Pieces of masking tape $50 \mathrm{~mm}$ long were folded and adhered to each end of the BHFs to serve as tabs. The BHFs were tested at $25 \mathrm{~mm} / \mathrm{min}$ and the data capture rate was $100 \mathrm{~Hz}$. The accuracy and reliability of test results were achieved by replicating the experiment 6 times for each bovine breed.

\subsubsection{Proximate Analysis}

The proximate compositions of the BHFs were manually determined by proximate analysis in accordance with AOAC 2003 standard [42]. Only the Crude Protein Content (CPC)\% of the BHFs is of relevance to the present study, hence it was determined along with the Moisture Content (MC) and Ash Content (AC) for all bovine breeds.

\subsubsection{SEM-EDS}

A single BHF was placed within the vacuum chamber located at the bottom of the scanning electron microscope column (German brand AURIGA, Carl Zeiss 2010 model). An electron source, located at the top of the column, produced electrons that passed through the column and were incident upon the BHF. The electron beam was directed and focused by magnets and lens inside of the scanning electron microscope column as it approached the BHF. The beam swung across the sample causing some of the electrons to be reflected by the BHF and some to be absorbed. Specialized X-ray detectors received these electrons and processed the signal into a usable format. The SEM-EDS was carried out on eight different spectra on a single BHF from each bovine breed, however, the closest four spectral details were selected for discussion in the present study.

\section{Results and Discussion}

\subsection{SEM-EDS Observations}

Figures 1-6 show the SEM-EDS results for the BHFs. Form the results, it was observed that for each bovine breed, elemental distributions differ significantly per spectrum in a single fiber. This is a general phenomenon observed with most NFs, and hitherto, there are no conclusive explanations for this incongruity. Many great attempts by researchers to explain this occurrence were implicit and tainted by many pitfalls. However, some researchers claimed that this occur- 


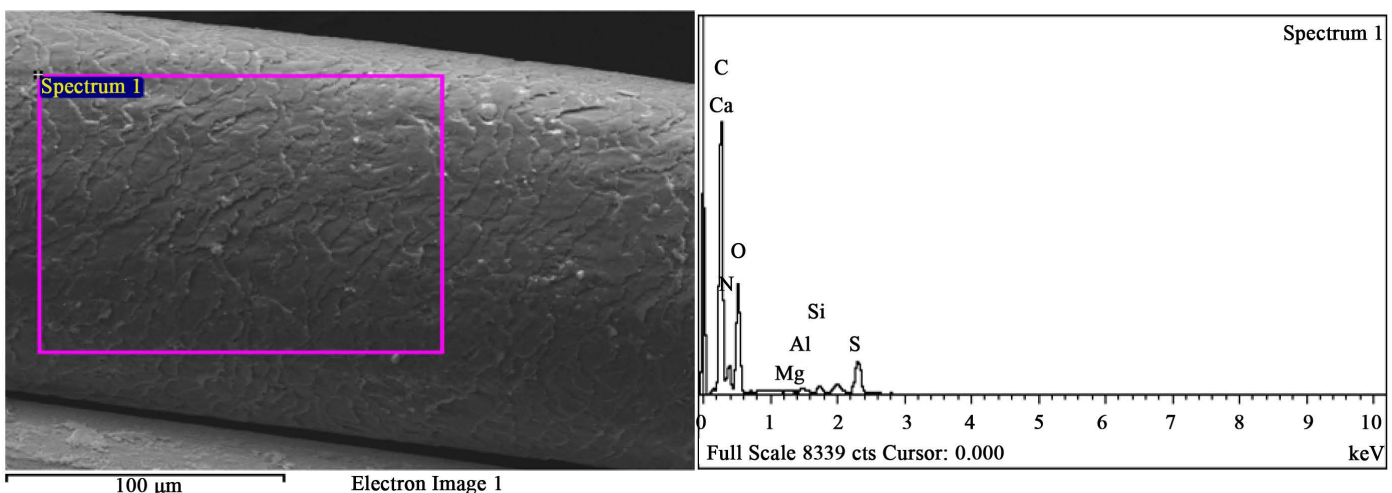

(a)

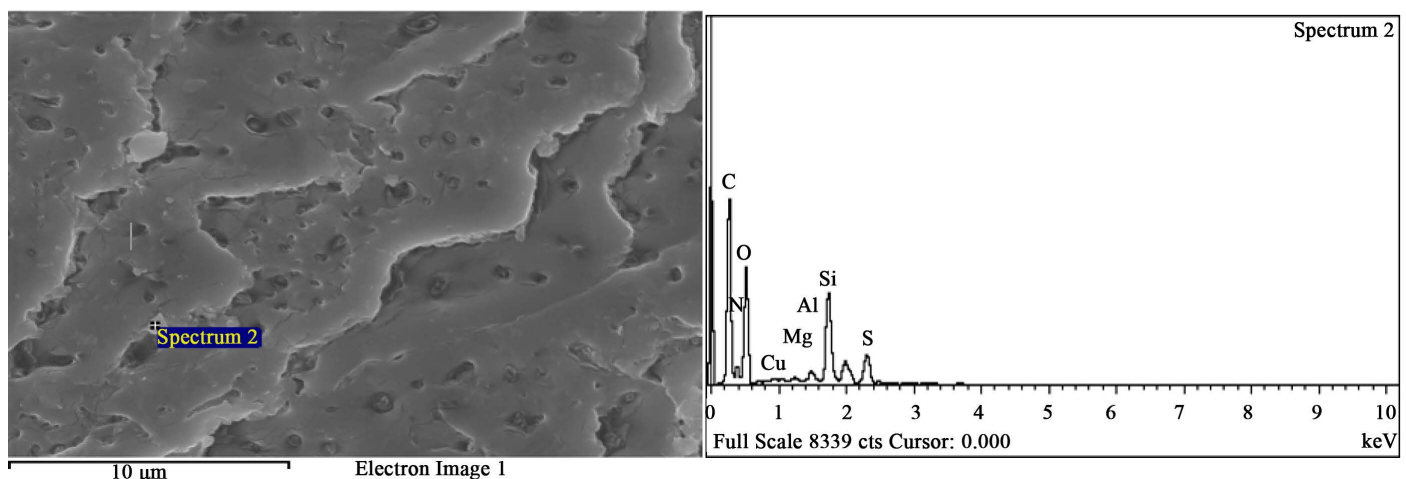

(b)

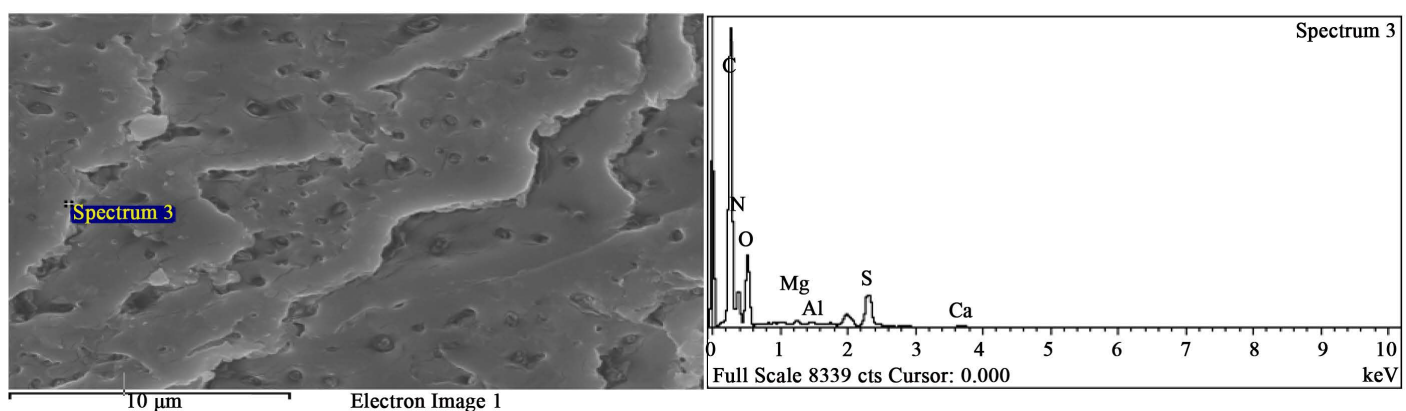

(c)

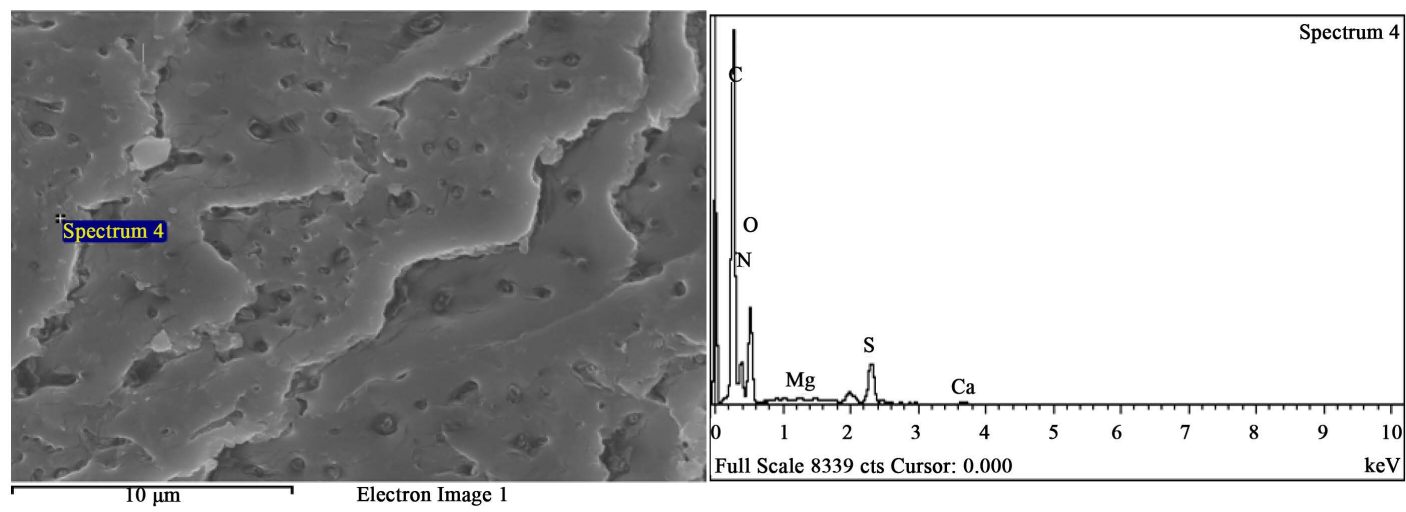

(d)

Figure 1. (a) Spectrum selected as spectrum 1 for the WHBHF; (b) Spectrum selected as spectrum 2 for the WHBHF; (c) Spectrum selected as spectrum 3 for the WHBHF; (d) Spectrum selected as spectrum 4 for the WHBHF. 


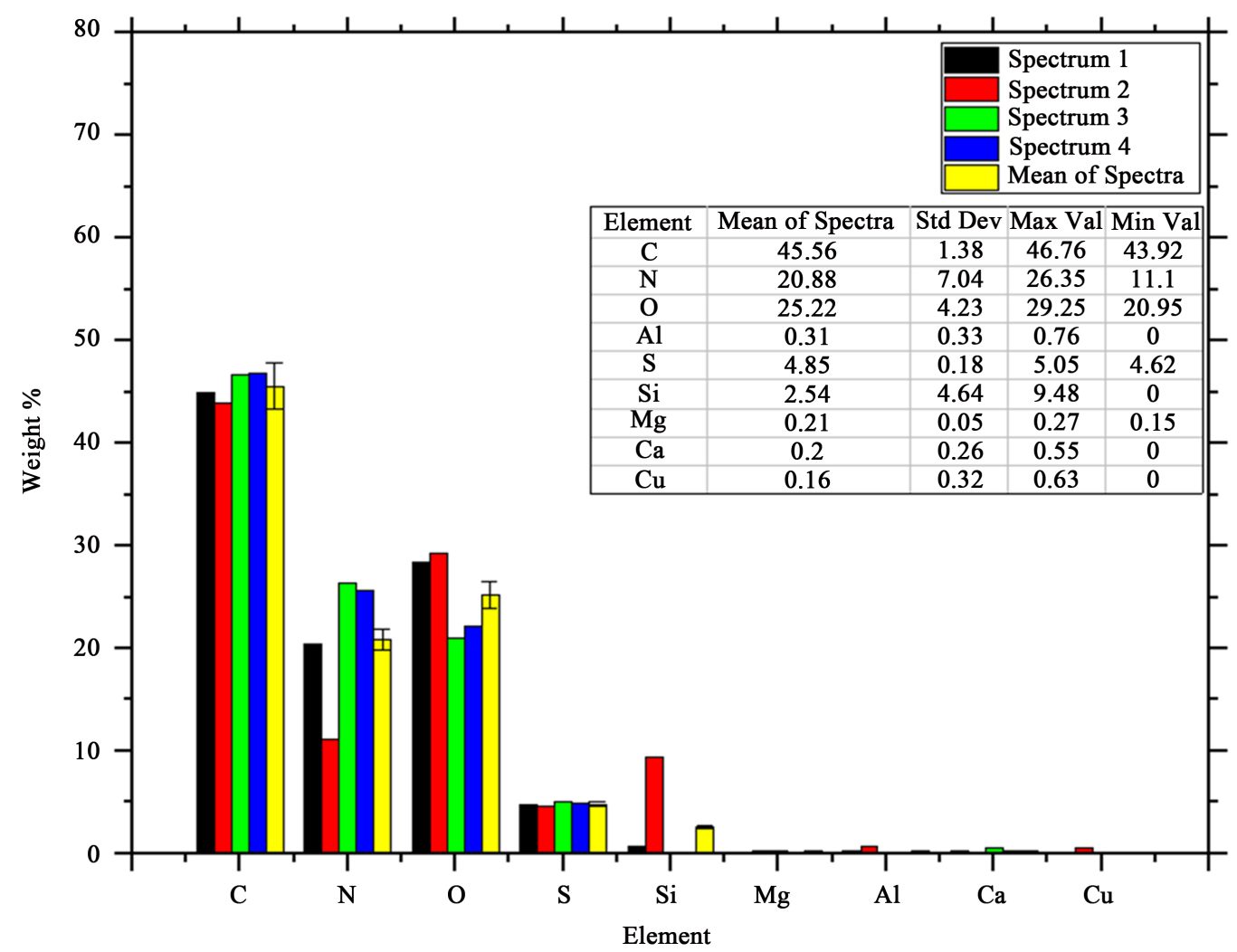

Figure 2. Quantitative SEM-EDS result for the WHBHF.

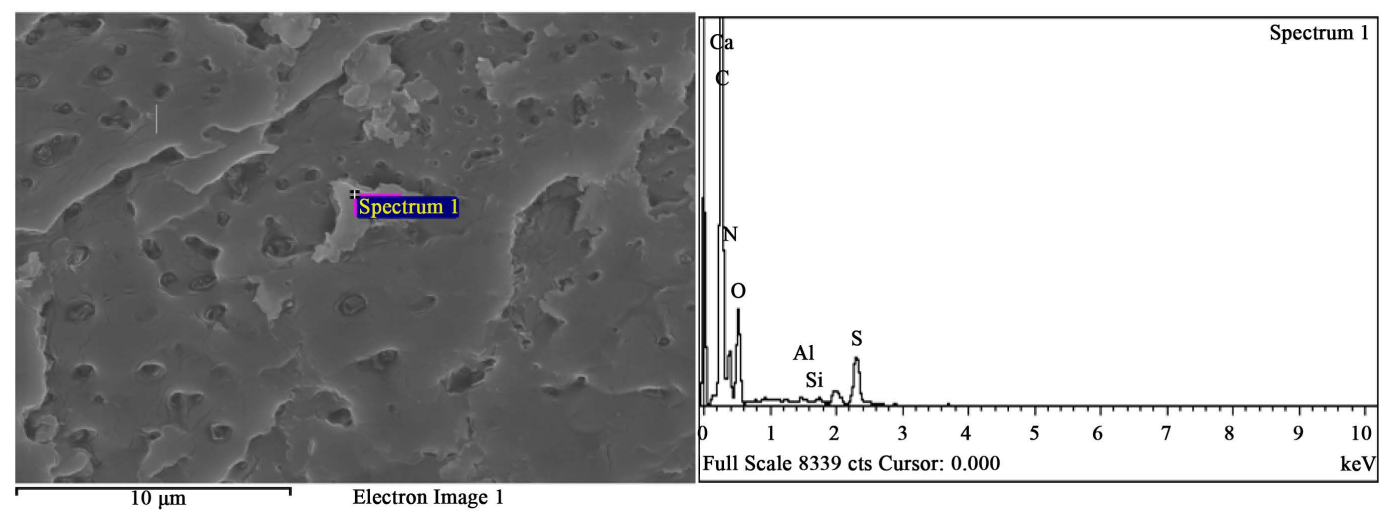

(a)

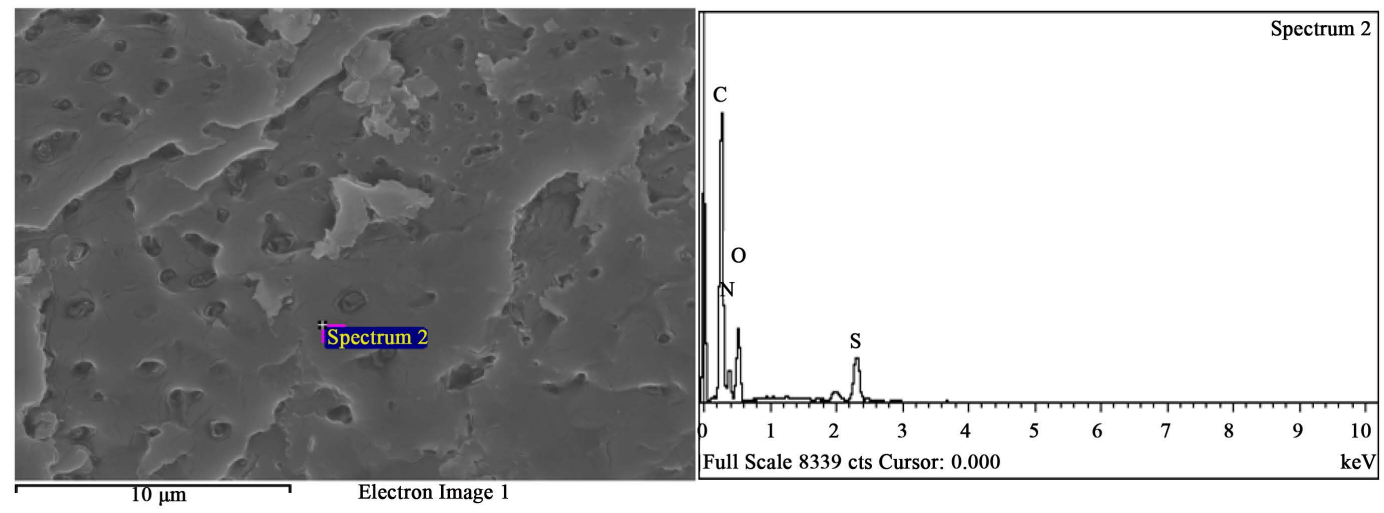

(b) 


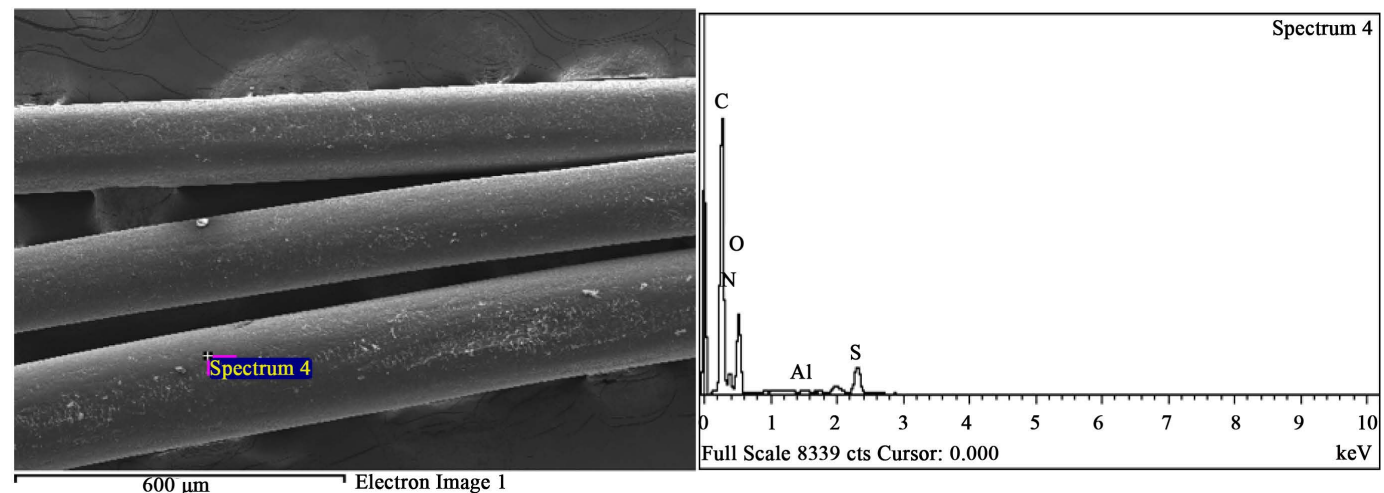

(c)

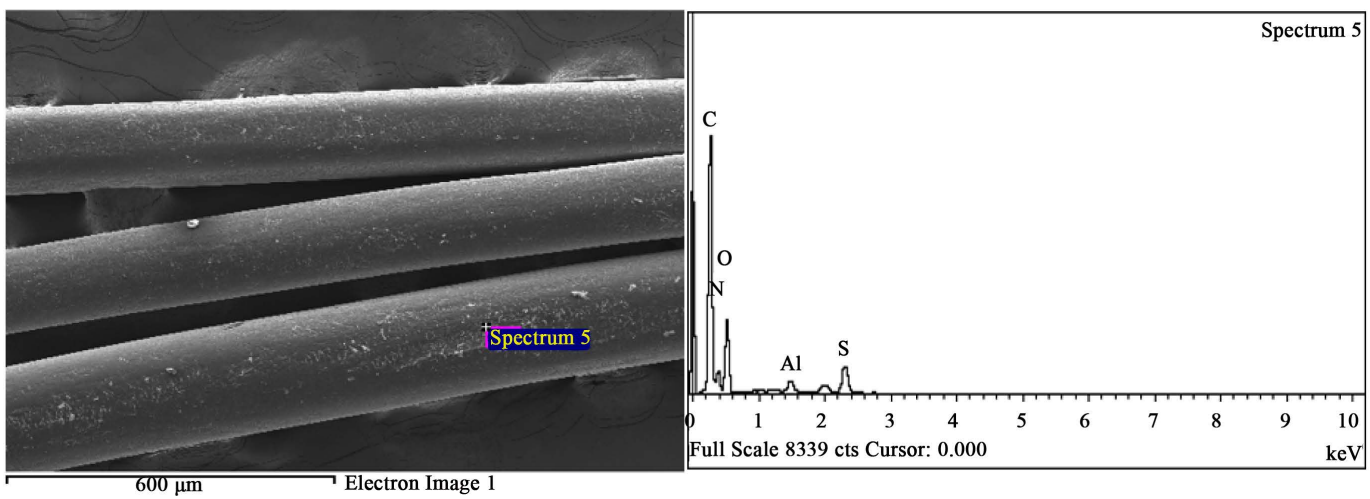

(d)

Figure 3. (a) Spectrum selected as spectrum 1 for the BLBHF; (b) Spectrum selected as spectrum 2 for the BLBHF; (c) Spectrum selected as spectrum 3 for the BLBHF; (d) Spectrum selected as spectrum 4 for the BLBHF.

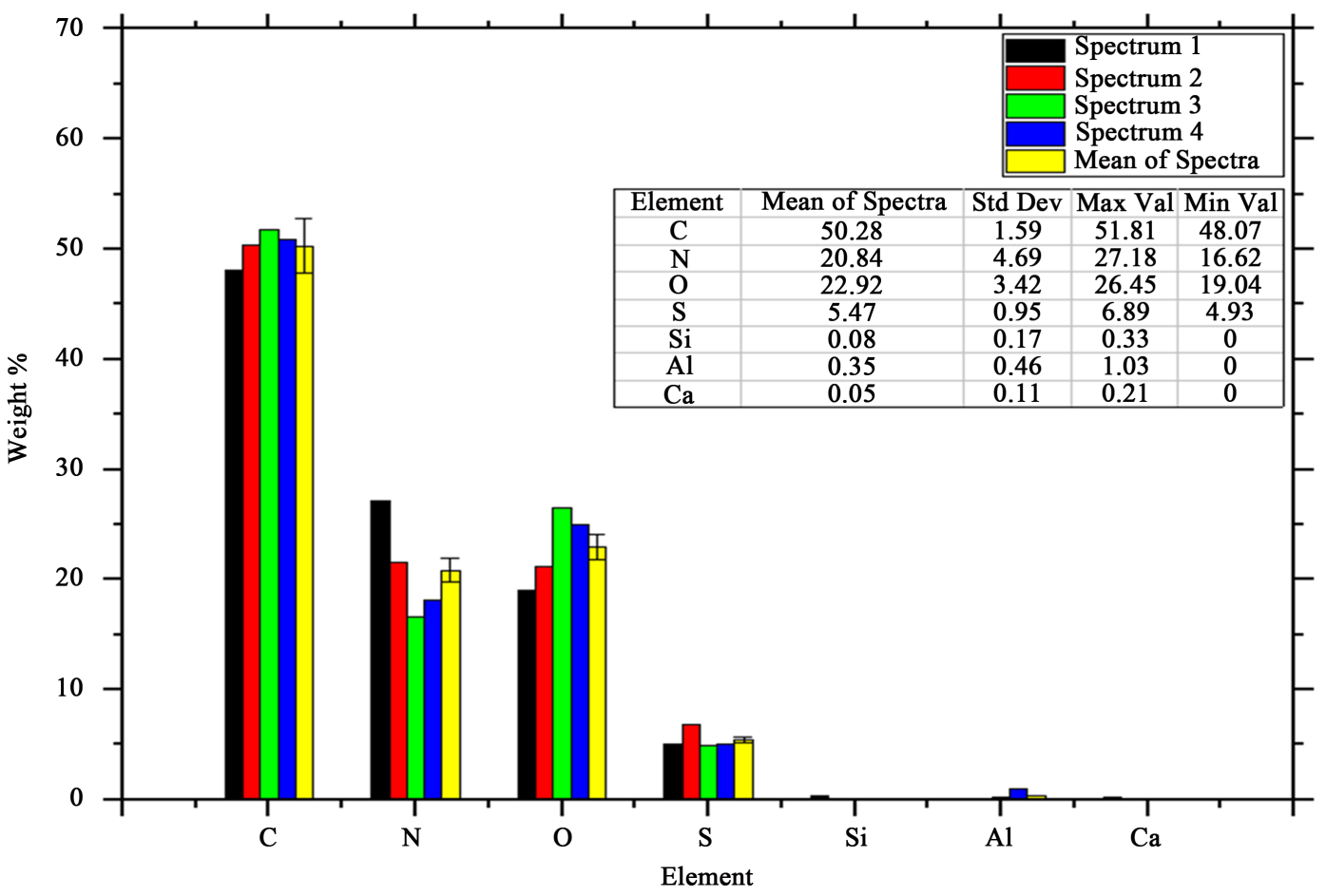

Figure 4. Quantitative SEM-EDS result for the BLBHF. 


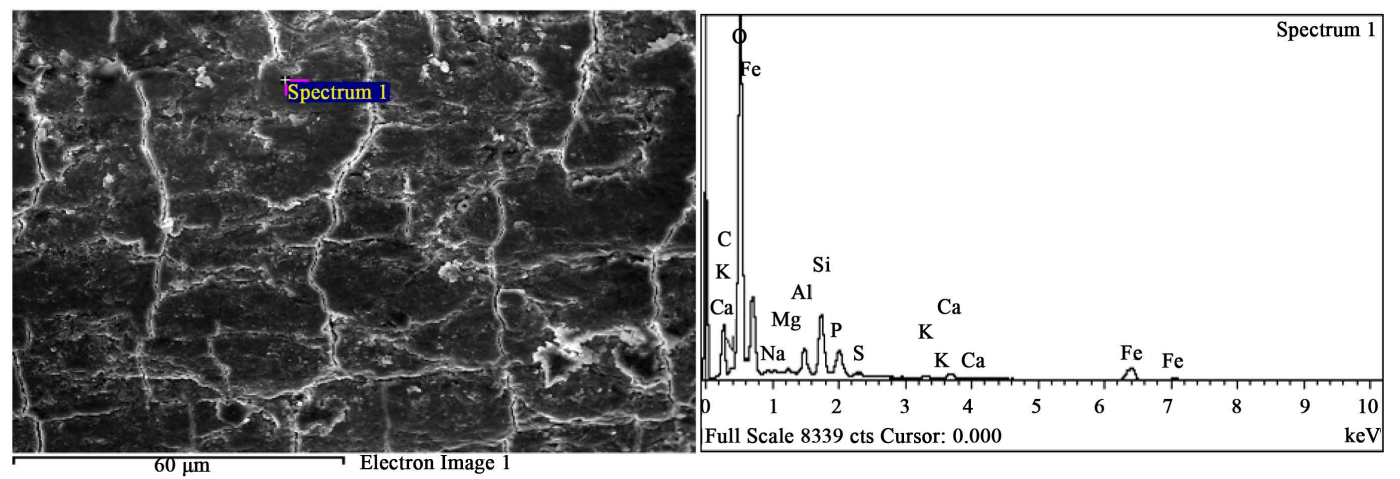

(a)

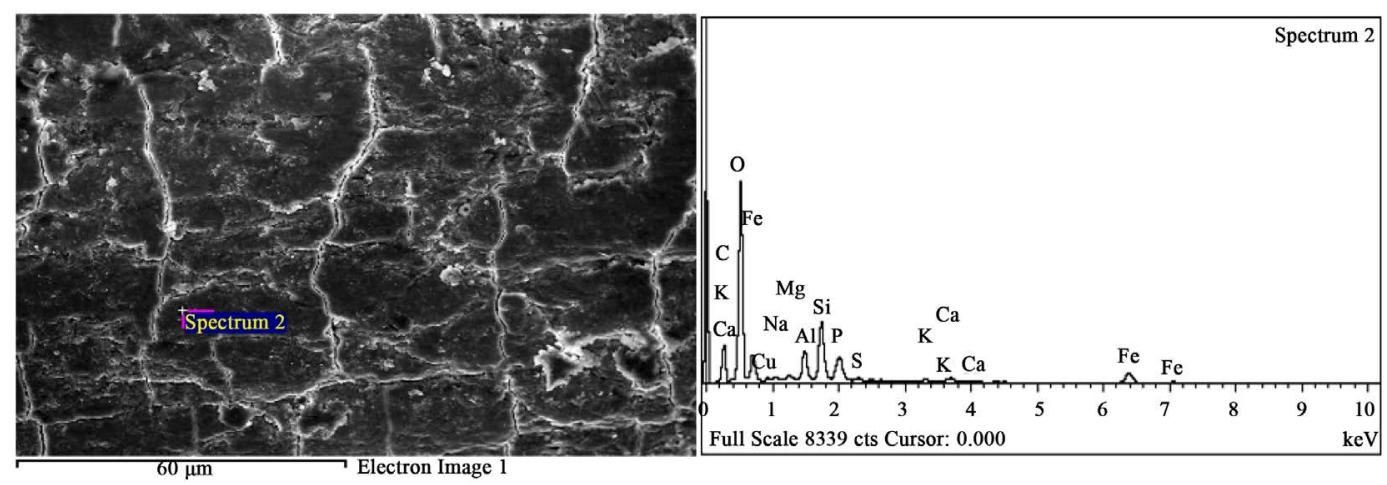

(b)

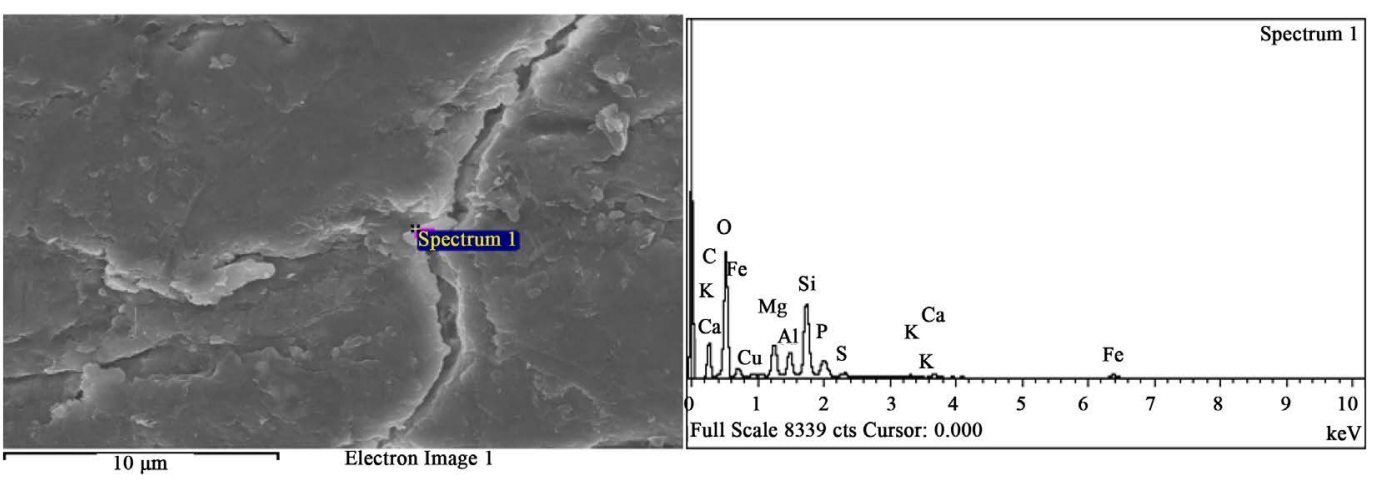

(c)

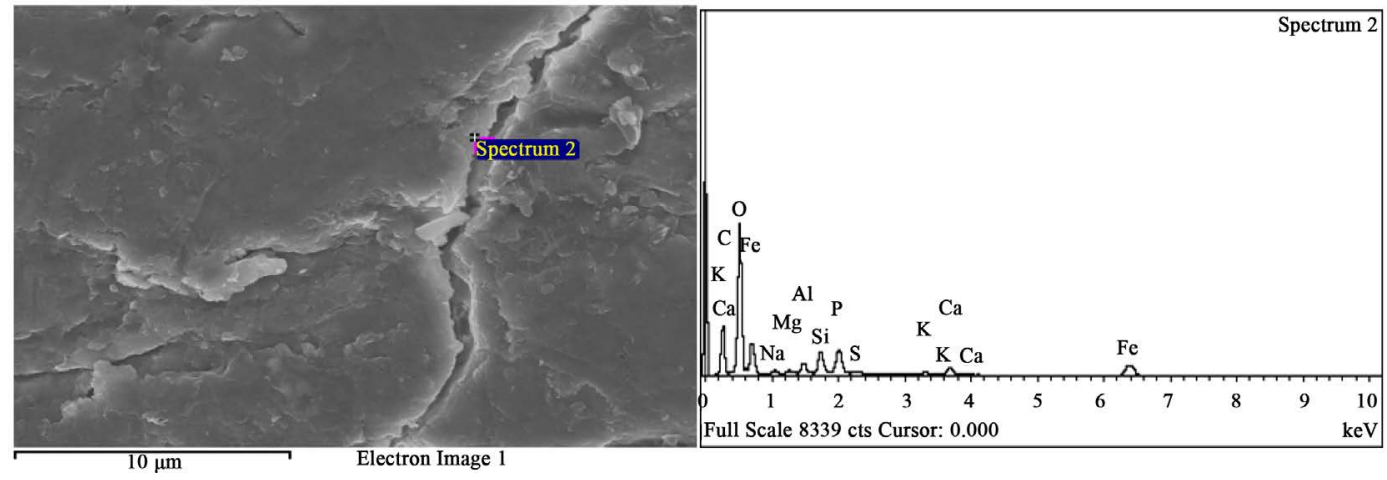

(d)

Figure 5. (a) Spectrum selected as spectrum 1 for the BRBHF; (b) Spectrum selected as spectrum 2 for the BRBHF; (c) Spectrum selected as spectrum 3 for the BRBHF; (d) Spectrum selected as spectrum 4 for the BRBHF. 


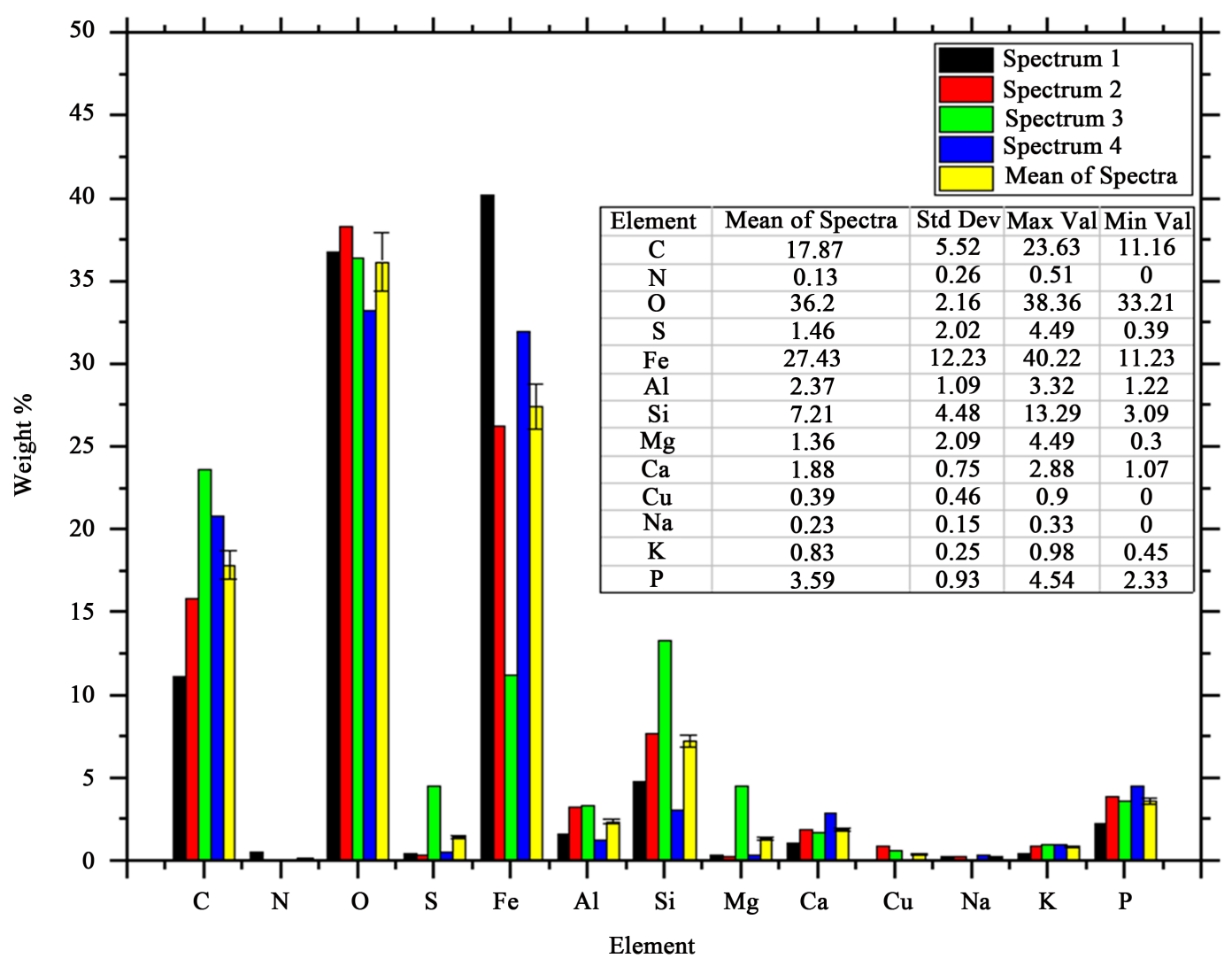

Figure 6. Quantitative SEM-EDS result for the BRBHF.

rence might be as a result of diametric inconsistency in a single NF, which in turn allows an inconsistent distribution of elements across the fiber's longitudinal and transverse sections [43].

Likewise, the elemental distributions of the BHFs vary with respect to bovine breeds. 13 elements were found in the BRBHF, 9 elements were found in the WHBHF and 7 elements were found in the BLBHF. However, 7 elements present in all the BHFs with different wt\% are Carbon, (C), Oxygen (O), Nitrogen $(\mathrm{N})$, Sulfur (S), Silicon (S), Calcium (Ca) and Aluminum (Al).

For the WHBHF and the BLBHF, $\mathrm{C}, \mathrm{N}, \mathrm{O}$ and $\mathrm{S}$ are present in significant amounts. Mean spectra values (MSVs) for $\mathrm{C}, \mathrm{N}, \mathrm{O}$ and $\mathrm{S}$ for the WHBHF are $45.56,20.88,25.22$ and $4.85 \mathrm{wt} \%$, respectively. For the BLBHF, the MSVs for C, $\mathrm{N}, \mathrm{O}$ and $\mathrm{S}$ are 50.28, 20.84, 22.92 and $5.47 \mathrm{wt} \%$, respectively. However, for the BRBHF, a different trend in the amount of significant elements present was observed. This fiber has very low $\mathrm{N}$ and $\mathrm{S}$ contents but has $\mathrm{C}, \mathrm{O}, \mathrm{Fe}, \mathrm{Si}$ and Phosphorus $(\mathrm{P})$ present in significant amounts. The MSVs for the C, O, Fe, Si and $\mathrm{P}$ present in this fiber are, 17.89, 36.20, 27.43, 7.21 and $3.59 \mathrm{wt} \%$, respectively.

The occurrence of variations in elemental distributions of hair fibers from different breeds of the same animal has explained by some trichologists is dependent on some specific factors. These factors include geographical location, environmental conditions, type of nutrition, health status, age and gender of the animal [44] [45]. 
From these observations, it can be said that BHF is not excluded from the blacklist of critical reviewers who have associated the limitations of NFs in NFRPCs development with their anisotropic properties. These researchers believe that glass fibers would still continue to dominate the fiber market as far as the development of FRPCs for load-bearing applications is concerned [46].

\subsection{Tensile Properties}

In Figure 7 the result of the uniaxial tensile tests of all the BHFs is presented. The Young's Modulus (Ymod), Ultimate Tensile Strength (UTS), Yield Strength (YS), Maximum Tensile Strain (Strain Max), Tensile Strain at Yield (Strain Yield) and Energy at Break (EBreak) for all the BHFs are presented. From the result, it was observed that the tensile properties of all the BHFs are relatively low in comparison with that of other NFs used as reinforcements in PCs.

The superlative tensile modulus exhibited by the BLBHF is $0.98089 \mathrm{GPa}$ which is considerably lower that of wool fiber (presumably the least stiff animal fiber known so far) with a tensile modulus of $3.4 \pm 0.1 \mathrm{GPa}$ [47]. The WHBHF and BRBHF have tensile moduli of 0.96092 and $0.78531 \mathrm{GPa}$, respectively.

In addition to the poor tensile properties, other shortcomings of BHFs are their short fiber length and high susceptibility to mechanical degradation if they are chemically modified. For most of the BHFs, the maximum fiber length attainable is $60 \mathrm{~mm}$ which in turn would limit the choices of fiber orientation in developing BHFRPCs. In terms of chemical modification of BHFs, the hydrophobic epithelial cuticle may be disrupted and expose the hydrophilic cortex of

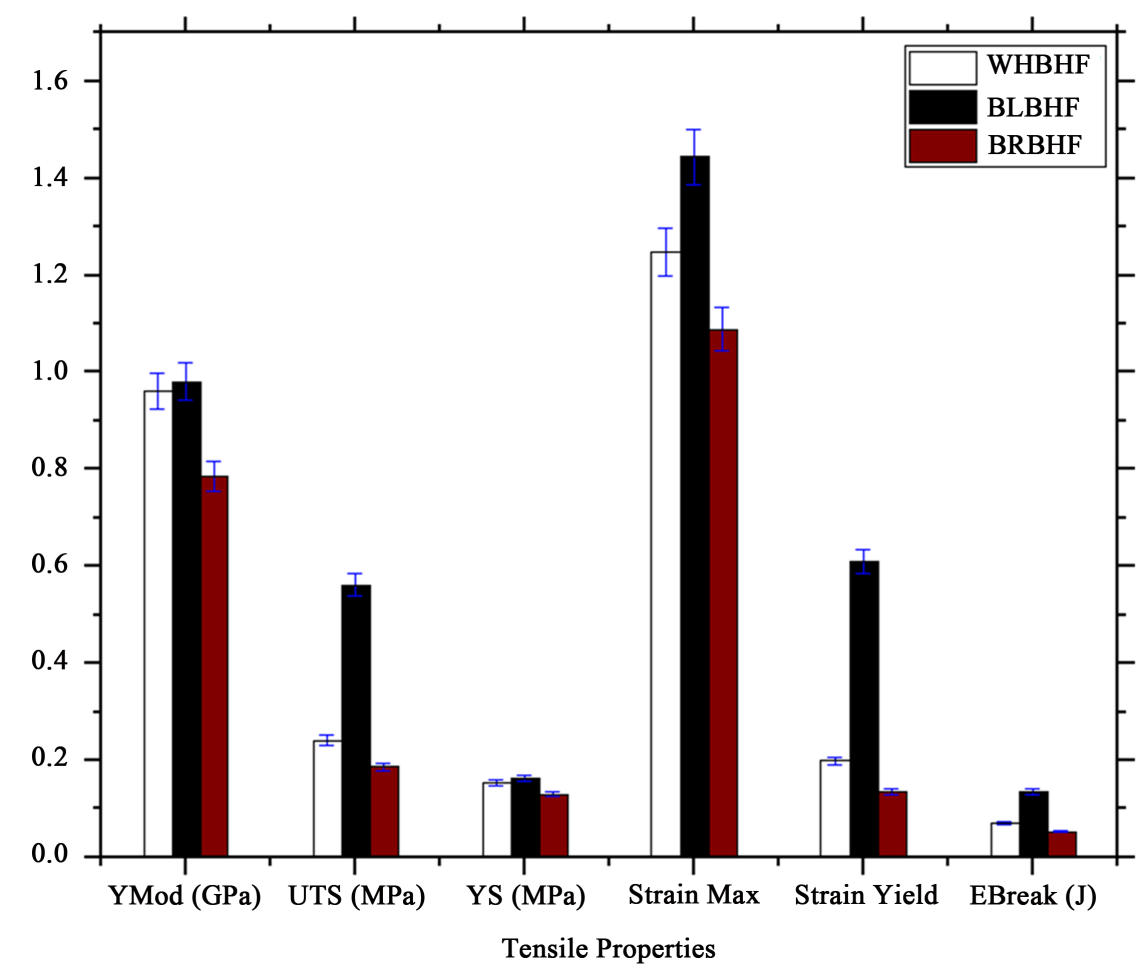

Figure 7. Tensile test result for the BHFs. 
the BHFs and this is likely to result in a swollen fiber [48]. Swollen fibers impede mechanical properties improvement in NFRPCs [49]. Furthermore, the possibility of getting sufficient BHFs with negligible deviations in properties from the same source of bovine breed(s) for BHFRPCs development is practically next to none.

Despite these exposed shortcomings of BHFs as an engineering material, the general claim used to support their emergent applications in AFRPCs development is their hydrophobic epithelial cuticle containing a lipid layer that includes 18-methyl eicosanoic acid (18 MEA) [50] which readily binds strongly with the hydrophobic polymer matrix in the absence of coupling agent and chemical modification of fiber surface.

Judging by these limitations, the present study considered it commendable for researchers with keen interest in exploiting BHFs for significantly useful purposes to seek alternative applications for this presently under-utilized bio-resource.

\subsection{Proximate Composition}

Of interest to the present study is the CPC\% of the BHFs, therefore their MC\% and AC\% would not be discussed. Prior exploiting AFs for keratin extraction, it is paramount to know the $\mathrm{CPC} \%$ present in the fibers as this gives an insight as to whether the exploitation would be worthwhile or not. Figure 8 shows the result of the proximate analysis for the BHFs. From the result, it was revealed that BHFs could be potential keratinous bio-resource based on their notable $\mathrm{CPC} \%$.

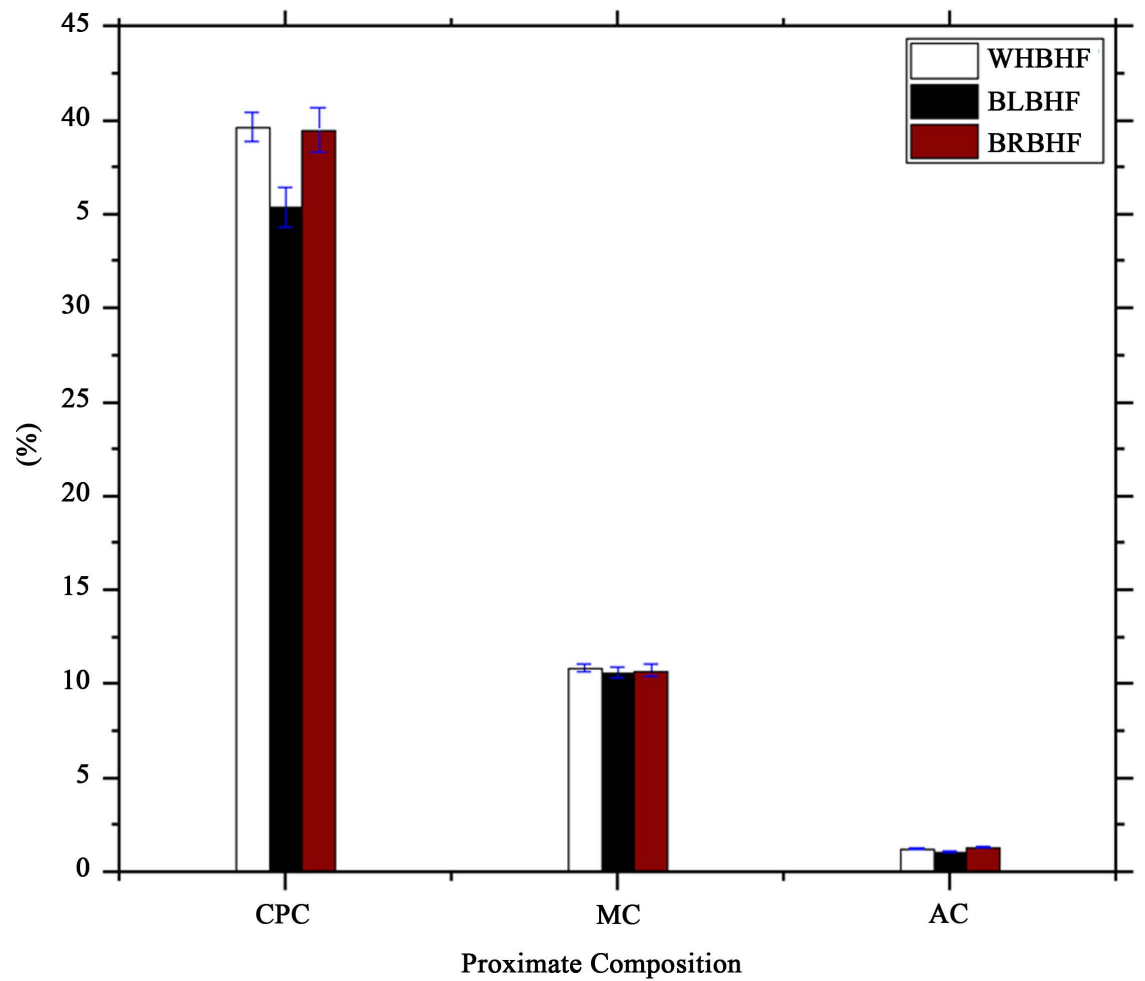

Figure 8. Proximate analysis result for the BHFs. 
This result is expected as some key elements such as $\mathrm{C}, \mathrm{N}, \mathrm{O}$ and $\mathrm{S}$ which are the building blocks of amino acids were detected in significant amounts by the spectroscopic analysis of the BHFs. The WHBHF and BRBHF have very close CPC\% which are $39.66 \%$ and $39.51 \%$, respectively. A slight drop in CPC\% was observed with the BLBHF having $35.77 \mathrm{CPC} \%$. A similar finding was reported by Oladele et al. when they investigated the effect of chemical treatments on CPC\% of Zebu breed bovine fiber [51].

According to Moore et al., the proximate composition may not give the exact protein content in a fiber [52]. However, the presence of elements such as $\mathrm{C}, \mathrm{N}$, $\mathrm{O}$ and $\mathrm{S}$ (key elements in amino acids) in significant amounts in the BHFs indicates that, with appropriate methods of extraction, substantial amount of useful keratins can be tapped from these fibers. The MSVs of the principal elements that constitutes amino acids in the fibers are in the same range with that of human hair fibers [53]. Human hair fibers have been successfully exploited for keratinous applications [37].

Presently, there exist many methods to extract keratin from BHF and other mammalian hair fibers. In a study conducted by Souza et al. on the feasibility of extracting keratin from BHF through hydrolysis, they were able to extract keratins with molecular weight of $20 \mathrm{kDa}$ [54]. Nakamura et al. used a novel method to extract hard $\alpha$-keratin with molecular masses of $40-60 \mathrm{kDa}$ from human hair waste [55]. Similarly, Fujii et al. developed a new procedure for extracting keratin from human hair waste without a surfactant agent, this approach resulted in a protein extraction yield greater than 70\% [56]. Recently, Burnett and Boyd received a US patent for inventing novel methods for extracting purified keratinbased biomaterials from different mammalian hair and avian feather wastes [57].

Any of the abovementioned methods can be adopted by researchers interested in the exploitation of BHFs for keratinous applications. A flowchart of possible extraction routes of keratins from BHFs and their potential areas of applications is presented in Figure 9.

\section{Conclusions}

The present study concluded from the observations from its experimental results, supporting research findings and theoretical facts that the exploitation of BHFs as reinforcements in PCs is an under-utilization of this bio-resource. This is dependent on the fact that their application is invariably limited to low loadbearing PCs. Furthermore, the field-proven reliability of BHFRPCs is still deeply rooted in the experimental phase.

Based on the foregoing revelations, a proper utilization of BHFs would be their exploitation for keratinous applications. This is basically because BHFs from different sources can be exploited simultaneously for keratin extraction, which may not be suitable for developing BHFRPCs due to the anisotropic properties of these fibers. 


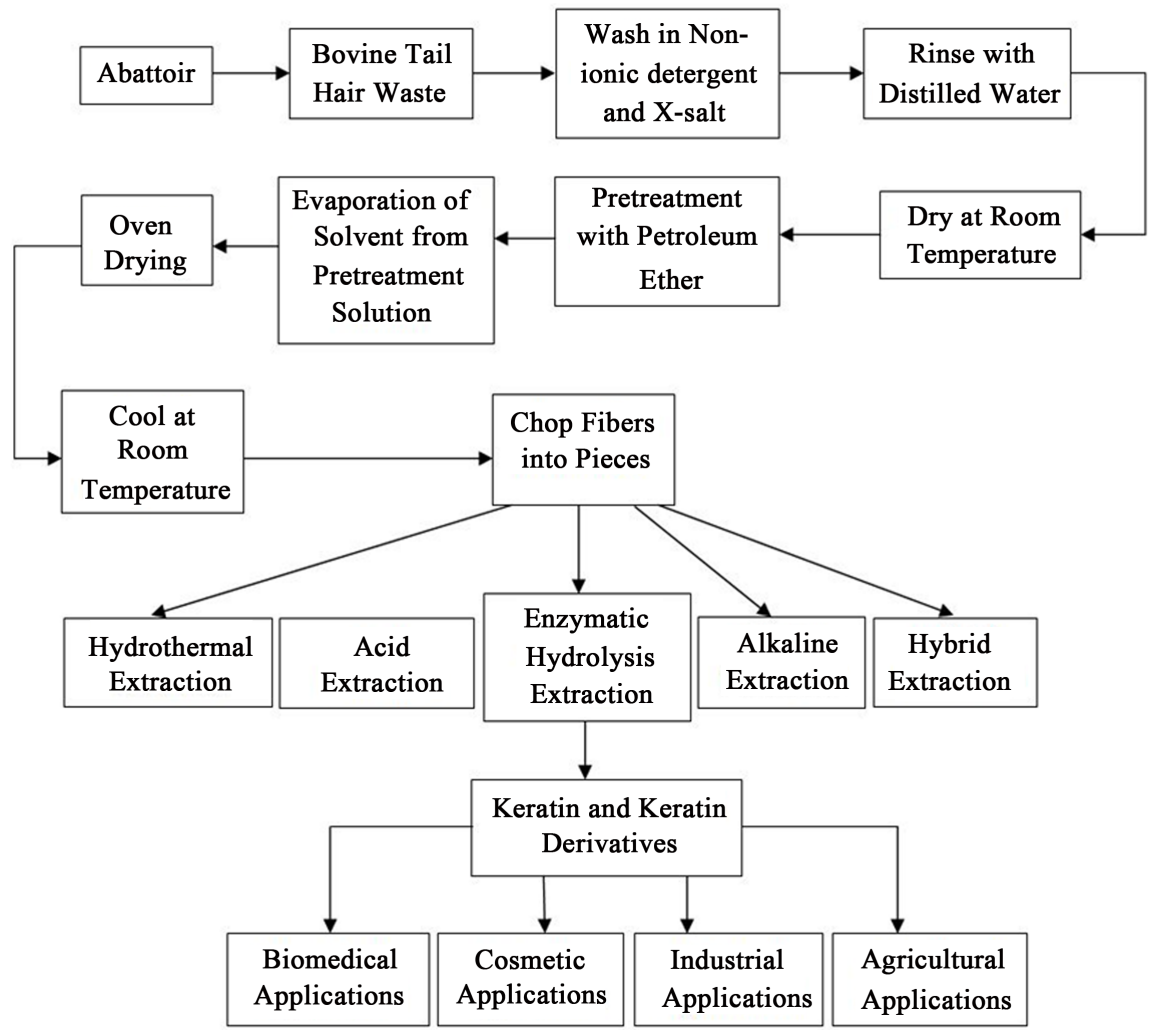

Figure 9. Flowchart of possible extraction routes of keratins from BHFs and their potential areas of applications.

However, in the absence of limited research facilities to exploit BHFs for keratinous application, the fibers still remain as good candidates for reinforcing low load-bearing polymer composites.

\section{References}

[1] Thomas, J.L. (2009) Why Are Natural Fibers Failing to Deliver on Composite Performance? 17th International Conference on Composite Materials, Edinburgh, 27-31 July 2009.

[2] Rowell, R.M., Sanadi, A.R., Caulfield, D.F. and Jacobson, R.E. (1997) Utilization of Natural Fibers in Plastics Composites: Problems and Opportunities. Lignocellulosic-Plastic Composite, 13, 23-51.

[3] Abilash, N. and Sivapragash, M. (2013) Environmental Benefits of Ecofriendly Natural Fiber reinforced Polymeric Composite Materials. International Journal of Application or Innovation in Engineering and Management, 2, 54-56.

[4] Pickering, K.L., Efendy, M.A. and Le T.M. (2016) A Review of Recent Developments in Natural Fiber Composites and their Mechanical Performance. Composites Part A: Applied Science and Manufacturing, 83, 98-112. https://doi.org/10.1016/j.compositesa.2015.08.038

[5] Sathishkumar, T.P., Navaneethkrishnan, P., Shankar, S., Rajasekar, R. and Rajini, N. (2013) Characterization of Natural Fiber and Composites: A Review. Journal of Reinforced Plastics and Composites, 32, 1457-1476. https://doi.org/10.1177/0731684413495322

[6] Mohammed, L., Ansari, M.N.M., Pua, G., Jawaid, M. and Islam, M.S. (2015) A Re- 
view on Natural Fiber Reinforced Polymer Composite and its Applications. International Journal of Polymer Science, 2015, 1-15. https://doi.org/10.1155/2015/243947

[7] Ashby, M.F. (2010) Materials Selection in Mechanical Design. 4th Edition, Butterworth Heinemann, New York.

[8] Sapuan, S.M., Kho, J.Y., Zainudin, E.S. and Hambali, A. (2011) Materials Selection for Natural Fiber Reinforced Polymer Composites Using Analytical Hierarchy Process. Indian Journal of Engineering and Materials Sciences, 18, 255-267.

[9] Ljunberg, L.Y. (2007) Materials Selection and Design for Development of Sustainable Products. Materials \& Design, 28, 466-479.

[10] Reich, S., ElSabbagh, A. and Steuernagel, L. (2008) Improvement of Fiber-Matrix Adhesion of Natural Fibers by Chemical Treatment. Macromolecular Symposia, 262, 170-181. https://doi.org/10.1002/masy.200850217

[11] Kabir, M.M., Wang, H., Lau, K.T. and Cardona, F. (2012) Chemical Treatments on Plant-Based Natural Fiber Reinforced Polymer Composites: An Overview. Composites Part B: Engineering, 43, 2883-2892.

https://doi.org/10.1016/j.compositesb.2012.04.053

[12] Mohanty, S. and Nayak, S.K. (2006) Interfacial, Dynamic Mechanical, and Thermal Fiber Reinforced Behavior of MAPE Treated Fiber Reinforced HDPE Composites. Journal of Applied Polymer Science, 102, 3306-3315. https://doi.org/10.1002/app.24799

[13] Zahari, W.Z., Badri, R.N., Ardyananta, H., Kurniawan, D. and Nor, F.M. (2015) Mechanical Properties and Water Absorption Behavior of Polypropylene/Ijuk Fiber Composite by Using Silane Treatment. Procedia Manufacturing, 2, 573-578. https://doi.org/10.1016/j.promfg.2015.07.099

[14] Monteiro, S.N., Lopez, F.P.D., Ferreira, A.S. and Nascimento, D.C.O. (2009) Natural Fiber Polymer Matrix Composites: Cheaper, Tougher, and Environmentally Friendly. The Journal of the Minerals, Metals \& Materials Society, 61, 17-22. https://doi.org/10.1007/s11837-009-0004-Z

[15] Thirmizir, M.A., Ishak, Z.M., Taib, R.M., Sudin, R. and Leong, Y.W. (2011) Mechanical, Water Absorption and Dimensional Stability Studies of Kenaf Bast FiberFilled Poly (Butylene Succinate) Composites. Polymer-Plastics Technology and Engineering, 50, 339-348. https://doi.org/10.1080/03602559.2010.531871

[16] Tajvidi, M. and Takemura, A. (2010) Recycled Natural Fiber Polypropylene Composites: Water Absorption/Desorption Kinetics and Dimensional Stability. Journal of Polymers and the Environment, 18, 500-509.

https://doi.org/10.1007/s10924-010-0215-y

[17] Shubhra, Q.T., Alam, A.K., Gafur, M.A., Shamsuddin, S.M., Khan, M.A., Saha, M., Sah, D., Quaiyyum, M.A., Khan, J.A. and Ashaduzzaman, M. (2010) Chararcterization of Plant and Animal Based Natural Fibers Reinforced Polypropylene Composites and Their Comparative Study. Fibers and Polymers, 11, 725-731. https://doi.org/10.1007/s12221-010-0725-1

[18] Gonçalves, S. and Esteves, J.L. (2007) Behavior of Wool Fibers Reinforced Composites Materials. 4th International Materials Symposium, Porto, 1-4 April 2007.

[19] Zhan, M., Wool, R.P. and Xiao, J.Q. (2011) Electrical Properties of Chicken Feather Fiber Reinforced Epoxy Composites. Composites Part A: Applied Science and Manufacturing, 42, 229-293. https://doi.org/10.1016/j.compositesa.2010.11.007

[20] Santulli, C., Sarasini, F., Tirillò, J., Valente, T., Valente, M., Caruso, A.P., Infantino, M., Nisini, E. and Minak, G. (2013) Mechanical Behavior of Jute Cloth/Wool Felts Hybrid Laminates. Materials \& Design, 50, 309-321.

https://doi.org/10.1016/j.matdes.2013.02.079 
[21] Oladele, I.O., Olajide, J.L., Agbabiaka, O.G. and Akinwumi, O.O. (2015) Tensile Properties and Fractographic Analysis of Low Density Polyethylene Composites reinforced with Chemically Modified Keratin-Based Biofibers. Journal of Minerals and Materials Characterization and Engineering, 3, 344-352. https://doi.org/10.4236/jmmce.2015.34037

[22] Ho, M.P., Wang, H., Lee, J.H., Ho, C.K., Lau, K.T., Leng, J. and Hui, D. (2012) Critical Factors on Manufacturing Processes of Natural Fiber Composites. Composites Part B: Engineering, 48, 3549-3562.

https://doi.org/10.1016/j.compositesb.2011.10.001

[23] Velasco, M.V., Dias, T.C., Freitas, A.Z., Jùnior, N.D., Pinto, C.A., Kaneko, T.M. and Baby, A.R. (2009) Hair Fiber Characteristics and Methods to Evaluate Hair Physical and Mechanical Properties. Brazilian Journal of Pharmaceutical Sciences, 45, 153162. https://doi.org/10.1590/S1984-82502009000100019

[24] Jayathilakan, K., Sultana, K., Radhakrishna, K. and Bawa, A.S. (2012) Utilization of Byproducts and Waste Materials from Meat, Poultry and Fish Processing Industries: A Review. Journal of Food Science and Technology, 49, 278-293. https://doi.org/10.1007/s13197-011-0290-7

[25] Frank-Whittle, I.H. and Insam, H. (2013) Treatment Alternatives of Slaughterhouse Wastes, and Their Effect on the Inactivation of Different Pathogens: A Review. Critical Reviews in Microbiology, 39, 139-151. https://doi.org/10.3109/1040841X.2012.694410

[26] Sharma, S. and Gupta, A. (2016) Sustainable Management of Keratin Waste Biomass: Applications and Future Perspectives. Brazilian Archives of Biology and Technology, 59, e16150684. https://doi.org/10.1590/1678-4324-2016150684

[27] Zoccola, M., Aluigi, A. and Tonin, C. (2009) Characterization of Keratin Biomass from Butchery and Wool Industry Wastes. Journal of Molecular Structure, 938, 35-40. https://doi.org/10.1016/j.molstruc.2009.08.036

[28] Rouse, J.G. and Van Dyke, M.E. (2010) A Review of Keratin-Based Biomaterials for Biomedical Applications. Materials, 3, 999-1014. https://doi.org/10.3390/ma3020999

[29] Vasconcelos, A. and Cavaco-Paulo, A. (2013) The Use of Keratin in Biomedical Applications. Current Drug Targets, 14, 612-619. https://doi.org/10.2174/1389450111314050010

[30] Barba, C., Méndez, S., Roddick-Lanzilotta, A., Kelly, R., Parra, J.L. and Coderch, L. (2008) Cosmetic Effectiveness of Topically Applied Hydrolysed Keratin Peptides and Lipids Derived from Wool. Skin Research and Technology, 14, 243-248. https://doi.org/10.1111/j.1600-0846.2007.00280.x

[31] Karthikeyan, R., Balaji, S. and Sehgal, P.K. (2007) Industrial Applications of Keratins: A Review. Journal of Scientific and Industrial Research, 66, 710-715.

[32] Adetunji, C.O., Makanjuola, O.R., Arowora, K.A., Afolayan, S.S. and Adetunji, B.O. (2012) Production and Application of Keratin-Based Organic Fertilizer from Microbially Hydrolyzed Feathers to Cowpea (Vigna unguiculata). International Journal of Scientific and Engineering and Research, 3, 1-9.

[33] Ayutthaya, S.I., Tanpichai, S. and Wootthikanokkhan, J. (2015) Keratin Extracted from Chicken Feather Waste: Extraction, Preparation, and Structural Characterization of the Keratin and Keratin/Biopolymer Films and Electrospuns. Journal of Polymers and the Environment, 23, 506-516. https://doi.org/10.1007/s10924-015-0725-8

[34] Zhan, M. and Wool, R.P. (2013) Thermal Expansivity of Chicken Feather Fiber reinforced Epoxy Composites. Journal of Applied Polymer Science, 128, 997-1003. 
https://doi.org/10.1002/app.38142

[35] Yin, X.C., Li, F.Y., He, Y.F., Wang, Y. and Wang, R.M. (2013) Study on Effective Extraction of Chicken Feather Keratins and Their Films for Controlling Drug Release. Biomaterials Science, 1, 528-536. https://doi.org/10.1039/c3bm00158j

[36] Wang, K., Li, R., Ma, J.H., Jian, Y.K. and Che, J.N. (2016) Extracting Keratin from Wool by Using L-Cysteine. Green Chemistry, 18, 476-481. https://doi.org/10.1039/C5GC01254F

[37] Lee, H., Noh, K., Lee, S.C., Kwon, I.K., Han, D.W., Lee, I.S. and Hwang, Y.S. (2014) Human Hair Keratin and Its-Based Biomaterials for Biomedical Applications. Tissue Engineering and Regenerative Medicine, 11, 255-265. https://doi.org/10.1007/s13770-014-0029-4

[38] Hu, W., Ton-That, M.T., Perrin-Sarazin, F. and Denault, J. (2010) An Improved Method for Single Fiber Tensile Test for Natural Fibers. Polymer Engineering and Science, 50, 819-825. https://doi.org/10.1002/pen.21593

[39] Bos, H.L., Van Den Oever, M.J. and Peters, O.C. (2002) Tensile and Compressive Properties of Flax Fibers for Natural Fiber Reinforced Composites. Journal f Materials Science, 37, 1683-1692. https://doi.org/10.1023/A:1014925621252

[40] Peponi, L., Biagiotti, J., Torre, L., Kenny, J.M. and Mondragon, I. (2008) Statistical Analysis of the Mechanical Properties of Natural Fibers and Their Composite Materials. I. Natural Fibers. Polymer Composites, 29, 313-320.

https://doi.org/10.1002/pc.20408

[41] ASTM D3822-07 (2007) Standard Test Method for Tensile Properties of Single Textile Fibers. ASTM International, West Conshohocken.

[42] AOAC (2003) Official Methods of Analysis of AOAC International. 17th Edition, Association of the Official Analytical Chemists (AOAC) International, Gaithersburg.

[43] Stocklassa, B., Aransay-Vitores, M., Nilsson, G., Karlsson, C., Wiegleb, D. and Forslind, B. (2000) Evaluation of a New X-Ray Fluorescent Analysis Technique for the Creation of a Nordic Hair Database: Elemental Distributions within the Root and Virgin Segment of Hair Fibers. Journal of Cosmetic Science, 52, 297-311.

[44] Sukumar, A. (2002) Factors Influencing Levels of Trace Elements in Human Hair. Reviews of Environmental Contamination and Toxicology, 175, 47-78.

[45] Combs, D.K. (1987) Hair Analysis as an Indicator of Mineral Status of Livestock. Journal of Animal Science, 65, 1753-1758. https://doi.org/10.2527/jas1987.6561753x

[46] Shah, D.U., Schubel, P.J. and Clifford, M.J. (2013) Can Flax Replace E-Glass in Structural Composites? A Small Wind Turbine Blade Case Study. Composites Part B: Engineering, 52, 172-181. https://doi.org/10.1016/j.compositesb.2013.04.027

[47] Basu, S. (2012) Tensile Deformation of Fibers Used in Textile Industry. http://cp.literature.agilent.com/litweb/pdf/5991-0274EN.pdf

[48] Dias, M.F. (2015) Hair Cosmetics: An Overview. International Journal of Trichology, 7, 2-15. https://doi.org/10.4103/0974-7753.153450

[49] Ramamoorthy, S.K., Di. Q., Adekunle, K. and Skrivars, M. (2012) Effect of Water Absorption on Mechanical Properties of Soybean Oil Thermosets Reinforced with Natural Fibers. Journal of Reinforced Plastics and Composites, 31, 1191-1200. https://doi.org/10.1177/0731684412455257

[50] Cruz, C.F., Costa, C., Gomes, A.C., Matamá, T. and Cavaco-Paulo, A. (2016) Human Hair and Impact of Cosmetic Procedures: A Review on Cleansing and ShapeModulating Cosmetics. Cosmetics, 3, 26.

https://doi.org/10.3390/cosmetics3030026 
[51] Oladele, I.O., Olajide, J.L. and Ogunbadejo, A.S. (2015) Effect of Chemical Treatments on the Physicochemical and Tensile Properties of Cow Hair Fibers for LowLoad Bearing Composites Development. International Journal of Materials Science and Applications, 4, 189-197. https://doi.org/10.11648/j.ijmsa.20150403.16

[52] Moore, J.C., DeVries, J.W., Lipp, M., Griffiths, J.C. and Abernethy, D.R. (2010) Total Protein Methods and Their Potential Utility to Reduce the Risk of Food Protein Adulteration. Comprehensive Reviews in Food Science and Food Safety, 9, 330-357. https://doi.org/10.1111/j.1541-4337.2010.00114.x

[53] Sustaita, H.C. (2016) A Close Look at the Properties of Hair and Scalp. www.texascollaborative.org/hildasustaita/module\%20files/topic3.htm

[54] Souza, F., Meyer, M., Wulf, H., Klüver, E., Cooper, M. and Gutterres, M. (2015) Extraction of Bovine Hair Keratin from Unhairing Wastes of Hide. 33th International Union of Leather Technologists and Chemists Societies Congress, Novo Hamburgo, 24-27 November 2015, 188-199.

[55] Nakamura, A., Arimoto, M., Takeuchi, K. and Fujii, T. (2002) A Rapid Extraction Procedure of Human Hair Proteins and Identification of Phosphorylated Species. Biological and Pharmaceutical Bulletin, 25, 569-572. https://doi.org/10.1248/bpb.25.569

[56] Fujii, T., Takayama, S. and Ito, Y. (2013) A Novel Purification Procedure for Keratin-Associated Proteins and Keratin from Human Hair. Journal of Biological Macromolecules, 13, 92-106.

[57] Burnett, L. and Boyd, S.A. (2012) Methods for Extracting Keratin Proteins. US Patent Applications 14/238,648.

Submit or recommend next manuscript to SCIRP and we will provide best service for you:

Accepting pre-submission inquiries through Email, Facebook, LinkedIn, Twitter, etc. A wide selection of journals (inclusive of 9 subjects, more than 200 journals)

Providing 24-hour high-quality service

User-friendly online submission system

Fair and swift peer-review system

Efficient typesetting and proofreading procedure

Display of the result of downloads and visits, as well as the number of cited articles

Maximum dissemination of your research work

Submit your manuscript at: http://papersubmission.scirp.org/

Or contact jmmce@scirp.org 